Selcuk Journal of Agriculture and Food Sciences

http://sjafs.selcuk.edu.tr/sjafs/index

Research Article
SJAFS

(2019) 33 (1), 1-6

e-ISSN: $2458-8377$

DOI: $10.15316 /$ SJAFS.2019.148

\title{
A Comparative Study of Crop Evapotranspiration Estimation by Three methods with Measured Crop Evapotranspiration in Konya Plain.
}

\author{
Sinan SÜHERI ${ }^{1, *}$, Peter Addo AMARKAI ${ }^{1}$, Duran YAVUZ ${ }^{1}$ \\ ${ }^{1}$ Selçuk University, Faculty of Agriculture, Department of Agricultural Structure and Irrigation, Konya, Turkey
}

\begin{tabular}{l}
\hline ARTICLE INFO \\
\hline Article history: \\
Received date: 11.02 .2019 \\
Accepted date: 28.02.2019 \\
\hline Edited by: \\
Kazım ÇARMAN; Selçuk University, \\
Turkey \\
Reviewed by: \\
Zeki GÖKALP; Erciyes Universiy, \\
Turkey \\
Yusuf UÇAR; Isparta University of \\
Applied Sciences, Turkey \\
\hline Keywords: \\
Evapotranspiration \\
Penman Monteith \\
Radiation Method \\
Hargeaves and Samani \\
Konya
\end{tabular}

\begin{abstract}
Evapotranspiration values are one of the basic data used in the planning, design, construction and operation of irrigation facilities. The irrigation water needs of several plants are calculated by using various empirical equations based on meteorological data and the system is designed according to the month in which the highest irrigation water is needed. The aim of this study is to compare ETc of several crops calculated with different ETc estimation methods as of FAO56-Penman-Monteith, Hergeaves - Samani and Radiation Equation with determined ETc values obtained from previously conducted researches in Konya. In the study, five commonly cultivated crops in Konya Province such as maize, sugar beet, sunflower, potato and wheat were considered. In most of the cases, it was found that radiation equation produced higher ETc values than the measured ETc values in the researches conducted at the region. As a result of this study, Penman-Monteith was close to most of the values obtained from other studies and therefore remains a highly recommendable method for estimating ETc for considered plants in Konya.
\end{abstract}

\section{Introduction}

Konya province located in the Central Anatolia has semi - arid climate with hot and dry summers. Annual precipitation in Konya is about $322.4 \mathrm{~mm}$ which is relatively low as compared to country average. A bit over 4 percent of the population are engaged in agricultural activities. Most of the crops cultivated in Konya require irrigation because of hot and dry summers.

Agriculture is one of the major ways to obtain nutrient, medicine, and other products for sustaining life and also contributes largely to the gross domestic product of most economies. Livelihood enhancement programs, food security, and other socioeconomic interventions over the years have targeted development in agriculture by increasing crop production through improvement in technology to be able to meet the needs of the world's increasing population. The World Bank (2018) has projected a world population of 9.7 billion by 2050 that is about $28 \%$ increase of the current population of 7.6 billion suggesting that food production in the future must be increased to be able to

\footnotetext{
*Corresponding author email: ssuheri@selcuk.edu.tr
}

match this growth. Climate on the other hand is known to affect food production in many ways. Climate is made up of many parameters including wind, air temperature, humidity, solar radiation, atmospheric pressure, and precipitation. All of these parameters are likely to change due to instability in the atmosphere. Variations in these parameters directly or indirectly affect agricultural activities.

Water plays a crucial role in agriculture; however, it is required to meet household, energy, manufacturing and ecological needs. Although the need for water is increasing in other sectors, irrigation continues to be the main consumer of water. According to the FAO (2018), the usage of water for irrigation generally amounts to about $70 \%$ of all freshwater withdrawals. Irrigation is a reliable way of providing plants with the water needed for growth and plant yield depends largely on the amount of water available and can be used at a particular period. Additionally, determining the amount of water needed by plants, and the amount that can be used by the plant for growth is necessary to determine the amount of water needed for irrigation to avoid excessive use of water and ensure plant growth.

Efficient management of declining water resources is an essential factor in achieving high irrigation 
efficiency, reducing drainage, decontamination of groundwater and desalination. The irrigation water efficiency can be increased by a proper irrigation program which includes the calculation of plant water consumption or crop evapotranspiration (ETc). Evapotranspiration is simply the amount of water lost through evaporation and transpiration and it can be expressed as a function of reference Evapotranspiration (ETo) and the crop coefficient (Kc).

Evapotranspiration values are one of the basic data used in the planning, design, construction and operation of irrigation facilities. When planning an irrigation system, possible crops that can be cultivated under irrigation are determined and the planting rates in the irrigation area are estimated. The irrigation water needs of these plants are calculated by using various empirical equations based on meteorological data and the system is designed according to the month in which the highest irrigation water is needed.

Table 1

Meteorological data of experimental area (2000-2010)

\begin{tabular}{lccccc}
\hline Months & $\begin{array}{c}\text { Mean Max } \\
\text { Temp }\left({ }^{\circ} \mathrm{C}\right)\end{array}$ & $\begin{array}{c}\text { Mean Min } \\
\text { Temp }\left({ }^{\circ} \mathrm{C}\right)\end{array}$ & $\begin{array}{c}\text { Monthly Sunshine } \\
\text { duration } \\
(\mathrm{n})(\text { Hours/Month) }\end{array}$ & $\begin{array}{c}\text { Monthly } \\
\text { average wind } \\
\text { speed (u2) }\end{array}$ & $\begin{array}{c}\text { Monthly mean } \\
\text { relative } \\
\text { humidity }(\%)\end{array}$ \\
\hline January & 5.65 & -3.05 & 103.05 & 2.12 & 82.19 \\
February & 7.24 & -2.39 & 136.03 & 2.82 & 76.87 \\
March & 13.79 & 1.05 & 196.02 & 3.22 & 64.65 \\
April & 17.4 & 4.78 & 208.6 & 3.04 & 63.3 \\
May & 23.07 & 9.26 & 267.49 & 2.9 & 56.64 \\
June & 28.1 & 14.06 & 296.69 & 3.36 & 46.97 \\
July & 31.3 & 17.37 & 328.17 & 3.68 & 41.49 \\
August & 31.69 & 17.6 & 319.18 & 3.32 & 39.5 \\
September & 26.43 & 12.37 & 266.11 & 2.75 & 49.62 \\
October & 20.32 & 7.35 & 213.3 & 2.48 & 62.38 \\
November & 13.25 & 1.42 & 158.38 & 2.2 & 75.73 \\
December & 6.75 & -2.2 & 102.12 & 2.08 & 83.35 \\
\hline
\end{tabular}

\subsection{Reference ETo calculations.}

Three ETo calculation methods as of FAO56Penman Monteith, Hargreaves and Samani, and Radiation equation were used to calculate ETo. The methods used in this study are cited and described in Allen et al. (1998), Hargreaves and Samani (1985) and Doorenbos and Pruitt (1977) respectively.

The FAO56 Penman Monteith method as stated by Allen et al. (1998) is

$$
\mathrm{ET}_{\mathrm{o}}=\left(\frac{0.408 \Delta\left(\mathrm{R}_{\mathrm{n}}-\mathrm{G}\right)+\gamma \frac{900}{\mathrm{~T}+273} \mathrm{u}_{2}\left(\mathrm{e}_{\mathrm{s}}-\mathrm{e}_{\mathrm{a}}\right)}{\Delta+\gamma\left(1+0.34 \mathrm{u}_{2}\right)}\right)
$$

Where; $\mathrm{Rn}=$ net radiation at the crop surface $[\mathrm{MJ}$ $\mathrm{m}^{-2}$ day $\left.^{-1}\right], \mathrm{G}=$ soil heat flux density $\left[\mathrm{MJ} \mathrm{m}{ }^{2}\right.$ day $\left.^{-1}\right]$, $\mathrm{T}=$ mean daily air temperature at $2 \mathrm{~m}$ height $\left[{ }^{\circ} \mathrm{C}\right], \mathrm{u}_{2}=$ wind speed at $2 \mathrm{~m}$ height [m s-1], es = saturation vapor pressure $[\mathrm{kPa}]$, ea $=$ actual vapor pressure $[\mathrm{kPa}]$, es ea $=$ saturation vapor pressure deficit $[\mathrm{kPa}], \Delta=$ slope
The aim of this study is to calculate ETc of several crops cultivated in Konya plain by using different ETc estimation methods and to compare estimated ETc values with determined ETc values obtained from previously conducted researches in the region.

\section{Materials and Methods}

\subsection{Study Area}

Konya where the research was conducted has arid climate conditions with hot and dry summers. According to long-term meteorological data (1929 2017), annual mean temperature, annual mean evaporation, annual mean precipitation are $11.6^{\circ} \mathrm{C}$, $1324 \mathrm{~mm}$ and $322.4 \mathrm{~mm}$, respectively.

Monthly measured data for 10 years (2000-2010) period were obtained from Konya meteorological station (latitude $37.9837 \mathrm{~N}$, longitude $32.5740 \mathrm{E}$, elevation $1031 \mathrm{~m}$ ) for calculation of ETo (reference crop evapotranspiration), (Table 1). vapour pressure curve $\left[\mathrm{kPa}{ }^{\circ} \mathrm{C}^{-1}\right], \gamma=$ psychrometric constant $\left[\mathrm{kPa}^{\circ} \mathrm{C}^{-1}\right]$.

The Hargreaves and Samani method as stated by Hargreaves and Samani (1985) is,

$$
\mathrm{ET}_{\mathrm{o}}=0.0023 \mathrm{Ra}\left(\mathrm{T}_{\max }-\mathrm{T}_{\text {min }}\right)^{0.5}\left(\mathrm{~T}_{\text {mean }}+17.8\right)
$$

Where; $\mathrm{Ra}=$ extraterrestrial radiation $\left(\mathrm{MJ} \mathrm{m}^{-2}\right.$ day $\left.{ }^{1} / 2.45\right)$, Tmin $=$ monthly minimum air temperature $\left({ }^{\circ} \mathrm{C}\right)$, Tmax $=$ monthly maximum air temperature $\left({ }^{\circ} \mathrm{C}\right)$, Tmean $=$ monthly mean air temperature $\left({ }^{\circ} \mathrm{C}\right)$.

The radiation method as stated by Doorenbos and Pruitt (1977) is

$$
\mathrm{ET}_{\mathrm{o}}=\mathrm{c}(\mathrm{W} * \mathrm{Rs})
$$

Where; ETo = reference crop evapotranspiration $\left(\mathrm{mm} \mathrm{day}{ }^{-1}\right), \quad$ Rs $=$ solar radiation in equivalent evaporation $\left(\mathrm{MJ} \mathrm{m}{ }^{-2}\right.$ day $\left.^{-1}\right), \mathrm{W}=$ weighting factor which depends on temperature and altitude, $\mathrm{C}=$ adjustment factor which depends on mean humidity 
and daytime wind conditions. W factor was calculated according to formula given by Doorenbos and Pruitt (1977)

$$
\mathrm{W}=\frac{\Delta}{\Delta+\gamma}
$$

Where; $\Delta=$ slope of the saturation vapour pressure temperature relationship $\left(\mathrm{kPa}^{\circ} \mathrm{C}^{-1}\right), \gamma=$ psychrometric constant $\left(\mathrm{kPa}^{\circ} \mathrm{C}^{-1}\right), \mathrm{C}$ factor was calculated according to formula given by Allen and Pruitt (1991)

$$
\begin{aligned}
& \mathrm{C}=1.066-0.00128 \mathrm{RH}_{\text {mean }}+0.045 \mathrm{U}_{\mathrm{d}}- \\
& 0.0002 \mathrm{RH}_{\text {mean }} \mathrm{U}_{\mathrm{d}}-0.0000315\left(\mathrm{RH}_{\text {mean }}\right)^{2}- \\
& 0.001103\left(\mathrm{U}_{\mathrm{d}}\right)^{2}
\end{aligned}
$$

Where; Rhmean=Mean relative 3 umidity $(\%), \mathrm{Ud}=$ mean wind speed at $2 \mathrm{~m}$

\begin{tabular}{|c|c|c|c|c|c|c|c|c|c|}
\hline \multirow[t]{2}{*}{ Crops } & \multirow{2}{*}{$\begin{array}{c}\text { Planting } \\
\text { date }\end{array}$} & \multirow{2}{*}{$\begin{array}{c}\text { Planting Time } \\
\text { (days) }\end{array}$} & \multicolumn{3}{|c|}{ Plating periods Kc coefficients } & \multicolumn{4}{|c|}{ Length of growth stages (days) } \\
\hline & & & $\mathrm{Kc}_{\text {ini }}$ & $\mathrm{Kc}_{\text {mid }}$ & $\mathrm{Kc}_{\mathrm{end}}$ & $\mathrm{I}$ & II & III & IV \\
\hline Maize & $10 / 05$ & 160 & 0.23 & 1.18 & 1.07 & 30 & 40 & 50 & 40 \\
\hline Potato & $10 / 04$ & 140 & 0.25 & 1.18 & 0.78 & 30 & 35 & 50 & 25 \\
\hline Sugarbeet & $1 / 04$ & 185 & 0.26 & 1.22 & 0.71 & 30 & 50 & 70 & 35 \\
\hline Sunflower & $20 / 04$ & 145 & 0.29 & 1.08 & 0.37 & 25 & 30 & 60 & 30 \\
\hline Wheat & $20 / 10$ & 270 & 0.63 & 1.16 & 0.27 & 170 & 30 & 40 & 30 \\
\hline
\end{tabular}

\subsection{Determination of Crop Evapotranspiration}

Table 2

Kc coefficients and planting periods of the crops for meteorological stations Anonymous (2016).

\section{Results and Discussion}

ETo results calculated using FAO-56 Penman Monteith, Hargreaves and Samani, and Radiation equation as presented in Table 3 shows an annual sum of 41.82, 38.69 and $50.86 \mathrm{~mm} /$ day and averages 3.49 , 3.22 and $4.24 \mathrm{~mm} /$ day respectively.

The Radiation equation produced the highest monthly ETo with a minimum of $0.95 \mathrm{~mm} /$ day and

Table 3

ETo values (mm/day) calculated with different methods.

\begin{tabular}{lccc}
\hline Months & $\begin{array}{c}\text { FAO56 - Penman } \\
\text { Monteith }\end{array}$ & Hargreaves and Samani & Radiation Equation \\
\hline January & 0.70 & 0.86 & 1.01 \\
February & 1.12 & 1.27 & 1.68 \\
March & 2.26 & 2.38 & 3.06 \\
April & 3.10 & 3.39 & 4.19 \\
May & 4.47 & 4.72 & 5.89 \\
June & 6.19 & 5.71 & 7.54 \\
July & 7.36 & 6.02 & 8.37 \\
August & 7.05 & 5.54 & 7.79 \\
September & 4.76 & 4.02 & 5.46 \\
October & 2.76 & 2.52 & 3.22 \\
November & 1.33 & 1.42 & 1.70 \\
December & 0.72 & 0.84 & 0.95 \\
\hline
\end{tabular}
Monteith method recorded a minimum of $0.70 \mathrm{~mm} /$ day and a maximum of $7.36 \mathrm{~mm} /$ day. Hargreaves and Samani method yielded values which are closer to FAO56-Penman Monteith in most months than the Radiation equation.

The highest ETo was $6.02 \mathrm{~mm} /$ day and a minimum value was $0.84 \mathrm{~mm} /$ day obtained by using Hargreaves and Samani estimation methods.
The Crop evapotranspiration was calculated with following formula given by (Allen et al., 1998)

$$
\mathrm{ETc}=\mathrm{Kc} \cdot \mathrm{ETo}
$$

Where; ETc $=$ crop evapotranspiration $\left(\mathrm{mm} \mathrm{day}^{-1}\right)$, $\mathrm{Kc}=$ crop coefficient, ETo $=$ reference crop evapotranspiration $\left(\mathrm{mm} \mathrm{day}^{-1}\right)$

The crop evapotranspiration of five different crops; maize (grain), sugar beet, sunflower, potato and wheat which are commonly cultivated on the region were calculated.

The Kc coefficients and planting periods were taken from Anonymous (2016). The Kc coefficients and growth periods of the crops for Konya meteorological stations are given in Table 2.

The Kc coefficients during initial and mid-season were considered as fixed. Kc coefficients for per month were determined graphically as stated by Allen et al. (1998).

maximum ETo of $8.37 \mathrm{~mm} /$ day. FAO56-Penman 
The calculated ETo was used to estimate the ETc of maize in this study as shown in Table 4. Maize plant has a growing period of 160 days that is from May to October and crop coefficient Kc of 0.22, 0.42, 1.06, 1.19, 1.16 and 1.10. The total ETc for maize was 817.83 , 682.96, and $934.85 \mathrm{~mm}$ according to the different methods. The highest ETc was obtained when the radiation equation was used whereas the least value was recorded when the Hargreaves and Samani method was used.

The ETc of the maize crop determined in a research conducted by Kara (2011) in 2009 at Konya. Kara (2011), investigated the effects of four different irrigation levels and 7 day irrigation interval on maize

Table 4

ETc of Maize calculated with different methods. yield and yield components. It was stated that total ETc of maize crop ranged between $590 \mathrm{~mm}$ and $781 \mathrm{~mm}$ in the study.

The researcher has indicated that the ETc was measured as $727.7 \mathrm{~mm}$ for the treatment where maximum yield was obtained.

In the another study conducted during the growing period in $2009-2010$, ETc values of maize were ranged between $555 \mathrm{~mm}$ and $779.1 \mathrm{~mm}$ for 2009, $602.4 \mathrm{~mm}$ and $812.5 \mathrm{~mm}$ for 2010. The ETc values of the treatment where the maximum yield obtained were $779,1 \mathrm{~mm}$ for 2009 and 812,5 mm for 2010 (Şahin et al., 2015).

\begin{tabular}{|c|c|c|c|c|c|c|c|c|}
\hline \multirow[b]{2}{*}{ Months } & \multirow[b]{2}{*}{ Days } & \multirow[b]{2}{*}{$\mathrm{Kc}$} & \multicolumn{2}{|c|}{ Penman Monteith } & \multicolumn{2}{|c|}{ Hergeaves Samani } & \multicolumn{2}{|c|}{ Radiation Equation } \\
\hline & & & $\begin{array}{c}\text { ETo } \\
\text { (mm/day) }\end{array}$ & $\begin{array}{c}\text { ETc } \\
\text { (mm/month) }\end{array}$ & $\begin{array}{c}\text { ETo } \\
\text { (mm/day) }\end{array}$ & $\begin{array}{c}\text { ETc } \\
(\mathrm{mm} / \mathrm{month})\end{array}$ & $\begin{array}{c}\text { ETo } \\
\text { (mm/day) }\end{array}$ & $\begin{array}{c}\text { ETc } \\
(\mathrm{mm} / \mathrm{month})\end{array}$ \\
\hline May & 21 & 0.22 & 4.47 & 20.65 & 4.72 & 21.81 & 5.89 & 27.21 \\
\hline June & 30 & 0.42 & 6.19 & 77.99 & 5.71 & 71.95 & 7.54 & 95.00 \\
\hline July & 31 & 1.06 & 7.36 & 241.85 & 6.02 & 197.82 & 8.37 & 275.04 \\
\hline Aug & 31 & 1.19 & 7.05 & 260.07 & 5.54 & 204.37 & 7.79 & 287.37 \\
\hline Sept. & 30 & 1.16 & 4.76 & 165.65 & 4.02 & 139.90 & 5.46 & 190.01 \\
\hline Oct. & 17 & 1.10 & 2.76 & 51.61 & 2.52 & 47.12 & 3.22 & 60.21 \\
\hline Total & 160 & & & 817.83 & & 682.96 & & 934.85 \\
\hline
\end{tabular}

When ETc values measured in Kara (2011) were compared with the ETc values estimated in this study, the ETc values calculated with FAO56-PenmanMonteith and Radiation Equation were higher than maximum ETc values calculated in Kara (2011). Hergeaves and Samani method produced closer ETc values to the measured ETc values.

Table 5

ETc of Sugar beet calculated with different methods.
It can be concluded that Radiation Equation overestimated the maize crop ETc in the region.

When ETc values measured in Şahin et al. (2015) were compared with the ETc values estimated in this study, it can be stated that Penman Monteith methods produced closer ETc values to the measured ETc values in the study.

\begin{tabular}{|c|c|c|c|c|c|c|c|c|}
\hline \multirow[b]{2}{*}{ Months } & \multirow[b]{2}{*}{ Days } & \multirow[b]{2}{*}{$\mathrm{Kc}$} & \multicolumn{2}{|c|}{ Penman Monteith } & \multicolumn{2}{|c|}{ Hergeaves Samani } & \multicolumn{2}{|c|}{ Radiation Equation } \\
\hline & & & $\begin{array}{c}\text { ETo } \\
\text { (mm/day) }\end{array}$ & $\begin{array}{c}\text { ETc } \\
(\mathrm{mm} / \mathrm{month})\end{array}$ & $\begin{array}{c}\text { ETo } \\
\text { (mm/day) }\end{array}$ & $\begin{array}{c}\text { ETc } \\
\text { (mm/month) }\end{array}$ & $\begin{array}{c}\text { ETo } \\
\text { (mm/day) }\end{array}$ & $\begin{array}{c}\text { ETc } \\
\text { (mm/month) }\end{array}$ \\
\hline April & 29 & 0.26 & 4.47 & 34.87 & 4.72 & 36.82 & 5.89 & 45.94 \\
\hline May & 31 & 0.60 & 4.47 & 83.14 & 4.72 & 87.79 & 5.89 & 109.55 \\
\hline June & 30 & 1.12 & 6.19 & 207.98 & 5.71 & 191.86 & 7.54 & 253.34 \\
\hline July & 31 & 1.23 & 7.36 & 280.64 & 6.02 & 229.54 & 8.37 & 319.15 \\
\hline Aug & 31 & 1.23 & 7.05 & 268.82 & 5.54 & 211.24 & 7.79 & 297.03 \\
\hline Sept. & 30 & 0.97 & 4.76 & 138.52 & 4.02 & 116.98 & 5.46 & 158.89 \\
\hline Oct. & 3 & 0.73 & 2.76 & 6.04 & 2.52 & 5.52 & 3.22 & 7.05 \\
\hline Total & 185 & & & 1020.01 & & 879.75 & & 1190.96 \\
\hline
\end{tabular}

The ETc of sugar beet calculated in this study were $1020.01 \mathrm{~mm}, 879.75 \mathrm{~mm}$, and $1190.96 \mathrm{~mm}$ using the Penman-Monteith, Hargreaves and Samani, and the Radiation equation as presented in Table 5. The growing period for sugar beet is 185 days. Higher ETc was recorded within the mid-season of the growing period.

Süheri et al. (2007) calculated the seasonal ETc of sugar beet throughout the development stages in 2005 and 2006. It was observed that ETc values ranged from $203 \mathrm{~mm}$ to $1177 \mathrm{~mm}$ in 2005 and $200 \mathrm{~mm}$ to $1002 \mathrm{~mm}$ in 2006 for the various seasons. The study also computed the ETc for the vegetative growth stage, root development stage, and ripening stage of sugar beet. ETc was mostly high during the root development stage.

Another study conducted in Konya by Poçan (2008) considered the calculation of seasonal and monthly ETc for sugar beet in 2006 and 2007. The total ETc ranged from $826 \mathrm{~mm}$ to $1135 \mathrm{~mm}$ in 2006 and $907 \mathrm{~mm}$ to $1182 \mathrm{~mm}$ in 2007 . 
Topak et al. (2016) conducted a study to compare partial root-zone drying with conventional deficit irrigation and full irrigation in Konya. The researches indicated that, the measured ETc values of sugar beet were ranged between $591.6 \mathrm{~mm}$ and $965.3 \mathrm{~mm}$ in the study.

When the total ETc results obtained from full irrigation treatments in this studies were compared with Table 6

ETc of Sunflower calculated with different methods.
ETc measured with the three methods, the radiation equation was higher than the maximum ETc obtained in Süheri et al. (2007) study, the maximum ETc calculated by Poçan (2008) and the maximum ETc calculated by Topak et al. (2016). . Penman-Monteith and Hargreaves and Samani method had ETc values within the ranges observed in Süheri et al. (2007), Poçan (2008) and Topak et al. (2016).

\begin{tabular}{|c|c|c|c|c|c|c|c|c|}
\hline \multirow[b]{2}{*}{ Months } & \multirow[b]{2}{*}{ Days } & \multirow[b]{2}{*}{$\mathrm{Kc}$} & \multicolumn{2}{|c|}{ Penman Monteith } & \multicolumn{2}{|c|}{ Hergeaves Samani } & \multicolumn{2}{|c|}{ Radiation Equation } \\
\hline & & & $\begin{array}{c}\text { ETo } \\
\text { (mm/day) }\end{array}$ & $\begin{array}{c}\text { ETc } \\
\text { (mm/month) }\end{array}$ & $\begin{array}{c}\text { ETo } \\
\text { (mm/day) }\end{array}$ & $\begin{array}{c}\text { ETc } \\
\text { (mm/month) }\end{array}$ & $\begin{array}{c}\text { ETo } \\
\text { (mm/day) }\end{array}$ & $\begin{array}{c}\text { ETc } \\
\text { (mm/month) }\end{array}$ \\
\hline April & 10 & 0.23 & 4.47 & 10.28 & 4.72 & 10.86 & 5.89 & 13.55 \\
\hline May & 31 & 0.36 & 4.47 & 49.89 & 4.72 & 52.68 & 5.89 & 65.73 \\
\hline June & 30 & 1.00 & 6.19 & 185.70 & 5.71 & 171.30 & 7.54 & 226.20 \\
\hline July & 31 & 1.09 & 7.36 & 248.69 & 6.02 & 203.42 & 8.37 & 282.82 \\
\hline Aug & 31 & 0.95 & 7.05 & 207.62 & 5.54 & 163.15 & 7.79 & 229.42 \\
\hline Sept. & 12 & 0.51 & 4.76 & 29.13 & 4.02 & 24.60 & 5.46 & 33.42 \\
\hline Total & 145 & & & 731.31 & & 626.00 & & 851.13 \\
\hline
\end{tabular}

The results of ETc for sunflower using PenmanMonteith, Hargreaves and Samani, and Radiation have been presented in Table 6 . The total growing period for sunflower is 145 days and the planting period started from April and end in September. The total ETc are $731.31 \mathrm{~mm}, 626 \mathrm{~mm}, 851.13 \mathrm{~mm}$.

Yavuz et al. (2016) calculated the ETc for sunflower cultivated in Konya with different irrigation interval in 2013 and 2014. The results of the study

Table 7

ETc of Potato calculated with different methods.

\begin{tabular}{lcccccccc}
\hline \multirow{2}{*}{ Months } & Days & \multicolumn{4}{c}{ Penman Monteith } & \multicolumn{2}{c}{ Hergeaves Samani } & \multicolumn{2}{c}{ Radiation Equation } \\
\cline { 3 - 8 } & & Kc & $\begin{array}{c}\text { ETo } \\
(\mathrm{mm} / \text { day })\end{array}$ & $\begin{array}{c}\text { ETc } \\
(\mathrm{mm} / \mathrm{month})\end{array}$ & $\begin{array}{c}\text { ETo } \\
(\mathrm{mm} / \text { day })\end{array}$ & $\begin{array}{c}\text { ETc } \\
(\mathrm{mm} / \mathrm{month})\end{array}$ & $\begin{array}{c}\text { ETo } \\
(\mathrm{mm} / \text { day })\end{array}$ & $\begin{array}{c}\text { ETc } \\
(\mathrm{mm} / \mathrm{month})\end{array}$ \\
\hline April & 20 & 0.25 & 4.47 & 22.35 & 4.72 & 23.60 & 5.89 & 29.45 \\
May & 31 & 0.44 & 4.47 & 60.97 & 4.72 & 64.38 & 5.89 & 80.34 \\
June & 30 & 1.09 & 6.19 & 202.41 & 5.71 & 186.72 & 7.54 & 246.56 \\
July & 31 & 1.18 & 7.36 & 269.23 & 6.02 & 220.21 & 8.37 & 306.17 \\
Aug & 28 & 1.00 & 7.05 & 197.40 & 5.54 & 155.12 & 7.79 & 218.12 \\
\hline Total & 140 & & & 752.36 & & 650.03 & & 880.64
\end{tabular}

Potato has a growing period of 140 days with crop coefficient $\mathrm{Kc}$ of $0.25,0.44,1.09,1.18$, and 1.00 were used to calculate the ETc using Penman-Monteith, Hargreaves and Samani, and radiation equation. The total ETc calculated using the methods are $752.36 \mathrm{~mm}$, $650.03 \mathrm{~mm}$, and $880.64 \mathrm{~mm}$. In the mid-season stage of potato, the ETc values were high for each of the methods.

Yavuz et al. (2012) also measured seasonal ETc in 2008 and 2009 of different irrigation methods for potato in Konya. The study determined the ETc for a sprinkler irrigation, furrow and drip irrigation system. The seasonal ETc in Yavuz et al. (2012) study were $665.69 \mathrm{~mm}, 614.64 \mathrm{~mm}$, and 581.54 in 2008 for each of the irrigation methods used. In 2009 the seasonal ETc estimated in Yavuz et al. (2012) study were $674.76 \mathrm{~mm}, 621.96 \mathrm{~mm}$, and $562.79 \mathrm{~mm}$. shows a total mean ETc ranging from $243.8 \mathrm{~mm}$ to $748.7 \mathrm{~mm}$ in 2013 and 2014.

ETc determined by the radiation equation in this study was higher than maximum ETc measured by Yavuz et al. (2016) The ETc values calculated with Hergeaves and Penman Monteith in this study were lower than maximum ETc values measured by Yavuz et al. (2016). However, Penman Monteith method produced closer ETc values to the ETc values measured by Yavuz et al. (2016). 
growth stages of wheat and water-deficit levels in Konya plain. The seasonal ETc was observed to be varied between 206 and $571 \mathrm{~mm}$ in the study.

When the results obtained from this study was compared to Tari (2016)'s, it was observed that Penman-Monteith method was about $18 \mathrm{~mm}$ higher

Table 8

ETc of Wheat calculated with different methods. than ETc determined in Tari (2016) study. The Hargreaves Samani was about $28 \mathrm{~mm}$ high when compared with the maximum ETc from Tari (2016) and the radiation equation was over $180 \mathrm{~mm}$ higher.

\begin{tabular}{|c|c|c|c|c|c|c|c|c|}
\hline \multirow[b]{2}{*}{ Months } & \multirow[b]{2}{*}{ Days } & \multirow[b]{2}{*}{$\mathrm{Kc}$} & \multicolumn{2}{|c|}{ Penman Monteith } & \multicolumn{2}{|c|}{ Hergeaves Samani } & \multicolumn{2}{|c|}{ Radiation Equation } \\
\hline & & & $\begin{array}{c}\text { ETo } \\
\text { (mm/day) }\end{array}$ & $\begin{array}{c}\text { ETc } \\
\text { (mm/month) }\end{array}$ & $\begin{array}{c}\text { ETo } \\
\text { (mm/day) }\end{array}$ & $\begin{array}{c}\text { ETc } \\
\text { (mm/month) }\end{array}$ & $\begin{array}{c}\text { ETo } \\
\text { (mm/day) }\end{array}$ & $\begin{array}{c}\text { ETc } \\
\text { (mm/month) }\end{array}$ \\
\hline January & 31 & 0.63 & 0.70 & 13.67 & 0.86 & 16.80 & 1.01 & 19.73 \\
\hline February & 28 & 0.63 & 1.12 & 19.76 & 1.27 & 22.40 & 1.68 & 29.64 \\
\hline March & 31 & 0.65 & 2.26 & 45.54 & 2.38 & 47.96 & 3.06 & 61.66 \\
\hline April & 30 & 0.93 & 3.10 & 86.49 & 3.39 & 94.58 & 4.19 & 116.90 \\
\hline May & 31 & 1.16 & 4.47 & 160.74 & 4.72 & 169.73 & 5.89 & 211.80 \\
\hline June & 30 & 0.9 & 6.19 & 167.13 & 5.71 & 154.17 & 7.54 & 203.58 \\
\hline July & 7 & 0.38 & 7.36 & 19.58 & 6.02 & 16.01 & 8.37 & 22.26 \\
\hline October & 21 & 0.63 & 2.76 & 36.51 & 2.52 & 33.34 & 3.22 & 42.60 \\
\hline November & 30 & 0.63 & 1.33 & 25.14 & 1.42 & 26.84 & 1.70 & 32.13 \\
\hline December & 31 & 0.63 & 0.72 & 14.06 & 0.84 & 16.41 & 0.95 & 18.55 \\
\hline Total & 270 & & & 588.62 & & 598.23 & & 758.85 \\
\hline
\end{tabular}

\section{Conclusion}

In conclusion, the results of this study suggest that the radiation method is not suitable in estimating plant water consumption in Konya because it produced the highest ETc in most cases, however, comparison with the other studies shows over estimated values which cannot be recommended for irrigation scheduling. Penman-Monteith was close to most of the values obtained from other studies and therefore remains a highly recommendable method for estimating ETc for considered plants in Konya.

\section{References}

Allen RG, Pruitt WO (1991). FAO-24 reference evapotranspiration factors. Journal of irrigation and drainage engineering 117 (5): 758-773.

Allen RG, Pereira LS, Raes D, Smith M (1998). Crop evapotranspiration-Guidelines for computing crop water requirements-FAO Irrigation and drainage paper 56. FAO, Rome 300 (9): D05109.

Anonymous (2016). Türkiye'de Sulanan Bitkilerin Bitki Su Tüketimi Rehberi, Tarımsal Araştırmalar ve Politakalar Genel Müdürlüğü. p., Ankara.

Doorenbos J, Pruitt W (1977). Crop water requirements. Irrigation and drainage paper no. 24. FAO, Rome

Hargreaves GH, Samani ZA (1985). Reference crop evapotranspiration from temperature. Applied engineering in agriculture 1 (2): 96-99.
Kara S (2011). Konya ekolojik koşullarında damla sulama yöntemi ile sulanan misır bitkisinde suverim ilişkileri, Selçuk Üniversitesi Fen Bilimleri Enstitüsü

Poçan M (2008). Farklı sulama aralıklarında sulamanın şeker pancarının verim ve kalitesi üzerine etkisi, Selçuk Üniversitesi Fen Bilimleri Enstitüsü

Süheri S, Topak R, Yavuz D (2007). Farklı Sulama Programlarının Şeker Pancarı Verimine Ve Su Kullanım Randımanına Etkisi. Selçuk Tarım Bilimleri Dergisi 21 (43): 37-45.

Şahin M, Süheri S, Yavuz D (2015). Damla Sulama ile Sulanan Misır Bitkisinde Farklı Bitki Sira ve Lateral Hat Aralıklarının Verim ve Su Kullanım Randımanına Etkisi Selçuk Üniversitesi BAP Projesi. Proje No: 09401066.

Tari AF (2016). The effects of different deficit irrigation strategies on yield, quality, and water-use efficiencies of wheat under semi-arid conditions. Agricultural Water Management 167: 1-10.

Topak R, Acar B, Uyanöz R, Ceyhan E (2016). Performance of partial root-zone drip irrigation for sugar beet production in a semi-arid area. Agricultural Water Management 176: 180-190.

Yavuz D, Kara M, Suheri S (2012). Comparison of different irrigation methods in terms of water use and yield in potato farming. J. Selcuk Univ. Nat. Appl. Sci 2: 1-12.

Yavuz N, Çiftçi N, Yavuz D (2016). The Effects of Deficit Irrigation on Yield of Sunflower. CHEMTECH'16: 20. 